\title{
Spatial Analysis the Potential for Energy Generation from Crop Residues in Shodirwan, Iran
}

\author{
A. Asakereh", M. Omid, R. Alimardani and F. Sarmadian \\ Faculty of Agricultural Engineering and Technology, School of Agricultural and \\ Natural Resources, University of Tehran, Iran \\ * Corresponding author E-mail: Asakereh@ut.ac.ir
}

\begin{abstract}
The purpose of this study was to analyse the spatial potential of crop residues with geographical information system (GIS) to generate energy in Shodirwan region, Iran. The available agriculture residues in Shodirwan were bagasse, sugarcane top, rice husk and straw of wheat, barley, bean, rice and mung bean. Results show that the total of crop residues that generated in this region was 1038525 tonnes/year and 668128 tonnes of them was available residues. The total potential of energy generation from available residues was $969589405 \mathrm{kWh} /$ year that sugarcane residues have the highest share with $79.15 \%$. Potential of energy generation from processing and field residues was 511946175 and 457643230 $\mathrm{kWh} /$ year, respectively. Spatial potential of residue to generate energy was calculated between 2900 to $61000 \mathrm{kWh} / \mathrm{hectare} / y e a r$. As a result of using energy of crop residues in Shodirwan, mitigation potential of $\mathrm{CO}_{2}$ emission was 554605 tonnes/year.
\end{abstract}

Keywords: Biomass energy, Crop residue, Energy, GIS, Iran

\section{Introduction}

Energy is an integral part of society and plays a pivotal role in its socio-economic development by raising the standard of living and the quality of life [1]. Fossil fuels have limited resources and, at current rates of exploitation, they are expected to deplete within the next century [2,3]. Furthermore, their over-utilization can cause environmental degradation due to incomplete combustion when used as an energy source. In addition to these issues, as the world population increases, demand for energy resources increases as well. These cases are the main reasons why clean, sustainable and environmentally friendly alternative energy resources are currently sought. Renewable energy has the capacity to provide cost-effective energy for remote communities without added investment of providing fossil generation. By 2050 , demand for energy could be doubled or even tripled as global population grows and developing countries expand their economies. Accordingly, all aspects of energy production and consumption, including energy efficiency, clean energy, global carbon cycle, carbon sources, sinks and biomass and their relationships with climatic and natural resource issues should be explored [4].

Biomass is a renewable energy source and its importance will increase as national energy policy and strategy focuses more heavily on renewable sources and conservation. Biomass energy has been attracting attention from the viewpoint of carbon dioxide mitigation by replacing fossil type fuel. If biomass is grown in a sustainable manner, utilization this energy does not add "new" carbon dioxide to the atmosphere, because the carbon dioxide released during combustion is offset by the carbon dioxide biochemically fixed by photosynthesis [57]. The energy stored within biomass can be effectively utilized as a carbon-neutral energy; 
hence countries throughout the world are pursuing the introduction of biomass energy systems [8].

Biomass energy still is the main energy source in many developing countries and regions so that provides roughly $35 \%$ of energy demand in developing countries $[7,9,10]$.

Iran's economy is heavily dependent on fossil fuels. Table 1 shows the present primary energy supply for Iran [11]. It is clear that primary energy supply of Iran depend on fossil fuel. Present biomass energy utilization is only a very small share with $0.365 \%$ of total Primary energy supply. Accordingly, this study mainly focuses on the agricultural residue of crop production.

Table 1. Primary Energy Supply Share of Iran (2011)

\begin{tabular}{lc}
\hline \multicolumn{1}{c}{ Energy resource } & $\begin{array}{c}\text { Energy supply share } \\
(\%)\end{array}$ \\
\hline Oil & 38.614 \\
Natural gas & 60.002 \\
Coal & 0.530 \\
Solid biomass and biogas & 0.368 \\
Hydro & 0.443 \\
Solar and wind & 0.006 \\
Nuclear & 0.037 \\
\hline
\end{tabular}

The main objective of the present study is to assess the potential of crop residues as sustainable sources of renewable energy in Shodirwan region, Iran. The biomass sources considered in this study include available residues from main types of agricultural crops.

\section{Methods and Materials}

\subsection{Study Area}

The study was carried out for Shodirwan region in Khuzestan province, Iran. This region is peninsula between Karun and Dez rivers and is the one of the important agriculture crop areas in Iran. Imam Khomeini agro-Industry with about 15000 hectares located in the middle of Shodirwan that sugarcane is cultivated in it. Data of different crop yield were collected by field random sampling and GPS was used to determine the location of sampling but data of sugarcane yield was obtained from Imam Khomeini agro-industry. Complementary data were collected from 300 farms by using a face-to-face questionnaire, corresponding governing, research institutes and available literature. Also GIS data have been obtained from the database published by Jahad Agriculture Organization of Khuzestan province and Iran National Cartographic Center. In the present work we used Arc GIS 9.3 as GIS software. The locations of the sampling points are shown in Figure 1. It is observed that the sampling wasn't done in the middle of study area, because yield data were obtained from the Imam Khomeini agro-industry. 


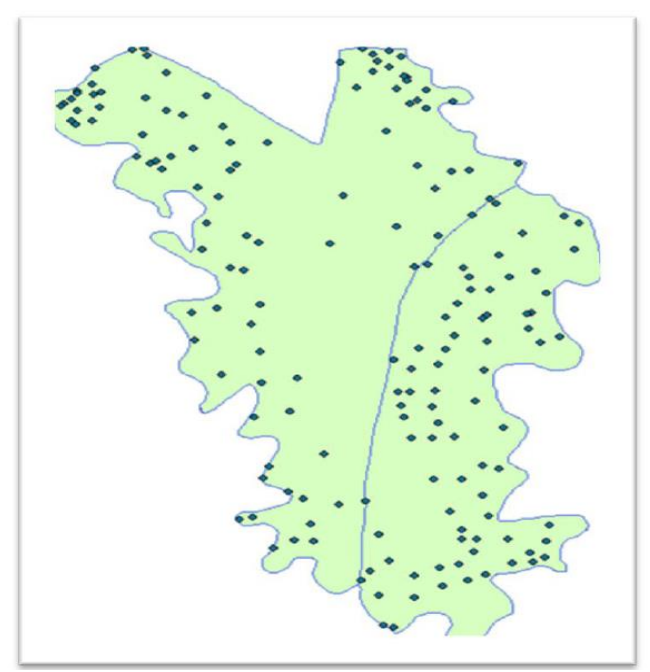

Figure 1. The Locations of the Sampling Points and Study Area

\section{2. Potential of Crop Residues in Shodirwan}

The most important crops in Shodirwan are wheat, barley, sugarcane, rice, bean, mung bean, jat and vegetable. There are two types of agricultural crop residues: field residues and processing residues [12]. Field residues can be collected, mostly by bailing, either at the same time or after the primary crop has been harvested. The most important field residues in Shodirwan are straw of wheat, barley, rice, bean, mung bean and sugarcane top and for processing residues are paddy husk and bagasse.

The annual gross potential of crop residues were obtained by calculating the production of agriculture crops in terms of yield and area in hectares for the year 2012 and then using residue to product ratio (RPR) to determine the amount of residue produced. RPR defined as the amount of residue production divided by agricultural production. The following form is used to cumulate potential of the gross potential of residue in each hectare [13, 14]:

$$
(C R)_{i}=(R P R)_{i} \times(\operatorname{PrC})_{i}
$$

where (CR)i is the amount of crop residues of ith crop in ton/hectare, (RPR)i the RPR of the ith crop and $(\mathrm{PrC}) \mathrm{i}$ the yield of crop production in ton/hectare. The all of field residues cannot be recoverable and utilized as an energy source, because percentage of field residues of a crop to be recycled onto the land depends upon the specific local climatic and soil conditions or use for domestic purposes, animal fodder, etc [12, 14]. Up to now, in Shodirwan, agriculture residues are not being used for energy generation in any case but only for animal feed and produce alcohol and MDF (medium density fibreboard) in Imam Khomeini agro-industry and most of them is burned by farmers in the field. However, in developed countries, it has been established that only 35\% of field crop residues can be removed without adverse effects on future yields. Crop processing residues, on the other hand, have a $100 \%$ recovery factor [12].

Energy potential from recoverable crop residues can be determined by multiplying the net supply potential of recoverable crop residue by the lower heating value (LHV). The RPR, recoverable factor $(\mathrm{RF})$ and LHV used in the present analysis are presented in Table 2 [12, 15-17]. 
Table 2. RPR, Recoverable Factor and LHV of Crop Residues

\begin{tabular}{llccc}
\hline Product & Residue & RPR & LHV $(\mathrm{MJ} / \mathrm{kg})$ & RF \\
\hline Sugar & Bagasse & $0.357^{*}$ & $17.81^{*}$ & 0.9 \\
& Sugar cane top & $0.25^{*}$ & $16.52^{*}$ & 0.7 \\
Paddy & Paddy husk & 0.2 & 12.98 & 0.9 \\
& Paddy straw & 1.7 & 16.7 & 0.35 \\
Wheat & Wheat straw & 1.75 & 17.9 & 0.35 \\
Barley & Barley straw & 1.75 & 17.9 & 0.35 \\
Bean & Bean straw & 1.9 & 17.46 & 0.35 \\
Mung bean & Mung bean straw & 1.9 & 17.5 & 0.35 \\
\hline
\end{tabular}

* Calculated in the Agro-industry

Energy potential of residue is estimated by $[14,18]$ :

$$
Q_{i}=\sum_{i=1}^{n}\left(C R_{i} \times R F_{i} \times L H V_{i}\right) \times n_{c}
$$

where Qi is the energy potential (GJ/h/year) of ith crop, LHVi the LHV of ith crop (GJ/t) and nc the conversion efficiency. A number of technologies with different efficiency exist for power generation from biomass. Agriculture biomass energy potential of wheat, corn, barley, rye, paddy, bagasse and other crops was estimated with combustion processes as direct fuel $[1,8,19-21]$. An overall efficiency of $30 \%$ was chosen, which a reachable level under current available technology is [21].

The geographical potential of biomass from crop residues can be developed with GIS. The results from field sampling and complementary data were plotted on a map of Shodirwan with longitude and latitude based on World Geodetic System 1984 (WGS84), and then, interpolated using inverse distance weighted (IDW), on ArcGIS. IDW is the interpolation method to estimate cell values by averaging the values of sample data points in the vicinity of each cell.

\section{Results}

Land use plays important role to use of renewable energy in each region. Figure 2 demonstrates Land use map classes for Shodirwan. It is obvious that the irrigated farming lands and Imam Khomeini agro-industrial have the largest share of Shodirwan area. Total irrigated farming land in Shodirwan is 88546 hectares while Total dry farming land is 4556 hectares. Non-agricultural land that don't have potential to produce crop residues, were identified with using land use map. 


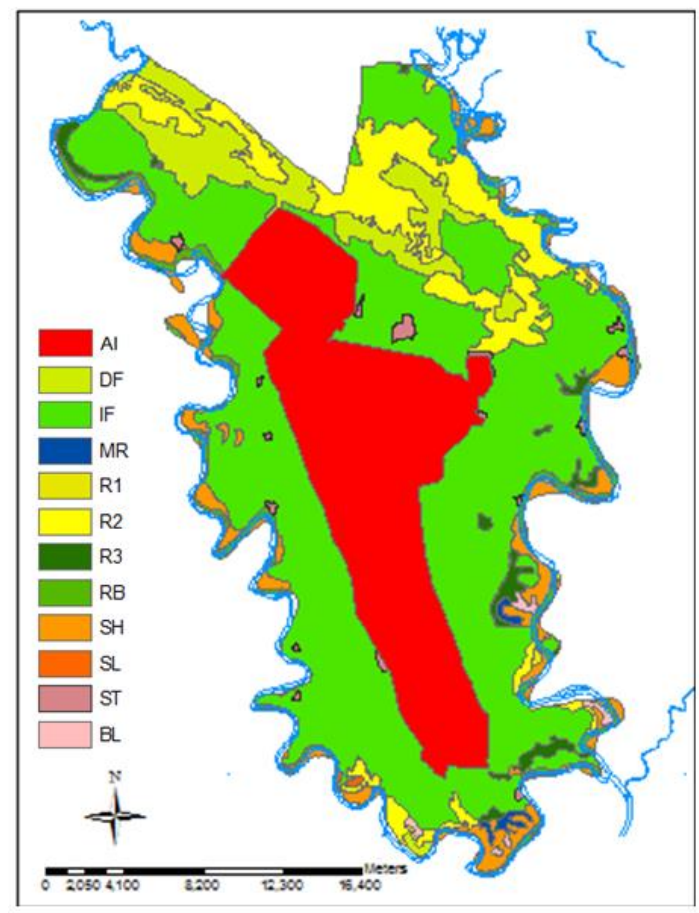

Figure 2. Land use (Al: Agro-industry, BL: Rocky protrusions, DF: Dry Farming, IF: Irrigated farming, MR: Marsh Land with High Level of Surfaces water, R1: Dense Rangeland, R2: Medium Dense Rangeland, R3: Poor Rangeland, RB: Large River Beds, SH: Shrub Land with more than 10 Percent Canopy Cover, SL: Salty Land, ST: Urban and Rural Area and Installations

Using land-use map and interpolation results, mops of available field crop residues were plotted and illustrated in Figure 3. Since the average sugarcane yield was between 77 to 80 tonnes/hectare, the sugarcane residues are far more than other crop residues. The large area of cultivation and good yield of irrigated wheat and barley caused good potential of available straw while in dry farming wheat and barley, yield is low and straw of them is little. So, dry farming was regardless to produce available residues. There are two cultivation seasons in Shodirwan: warm and cool season. Wheat and barley is cultivated in cool season while bean, paddy and mung bean are cultivated in warm season. The annual agricultural residue production and energy potentials of them in Shodirwan are presented in Table 3. The total of crop residues that produced in this region was 1038525 tonnes/year that 668128 tonnes of it was available residues. Maximum of available crop residue related to bagasse with 343591 tonnes. Total sugarcane residue (bagasse and top) was 649031 tonnes/year and available residue of it was 530675 tonnes. Sugarcane residues were followed by available straw of wheat and barley with 88545 tonnes/year. 


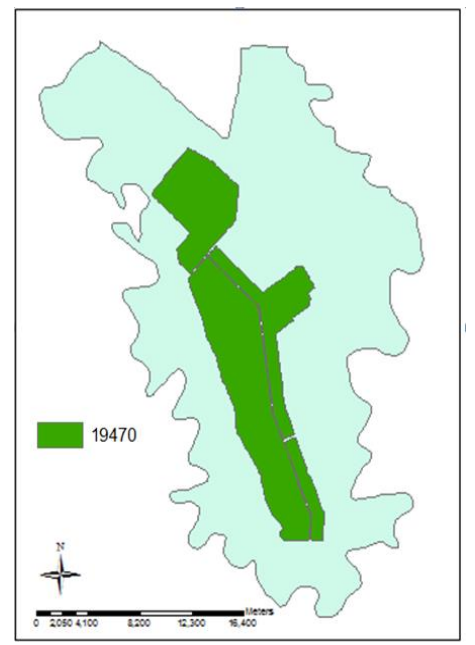

a) Sugarcane top

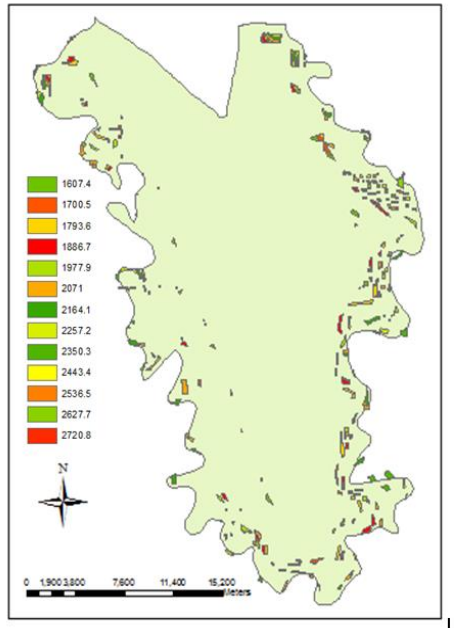

d) mung bean straw

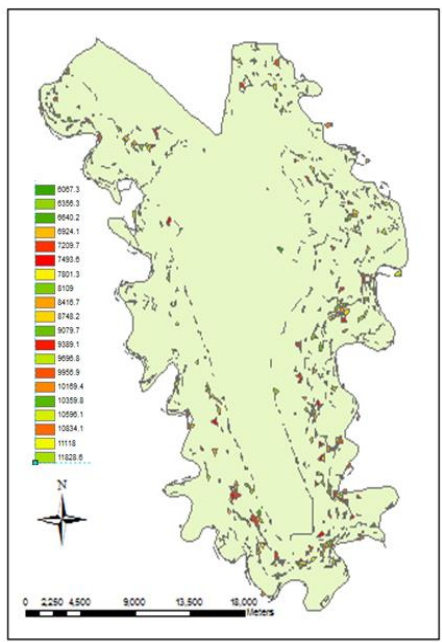

b) Paddy straw

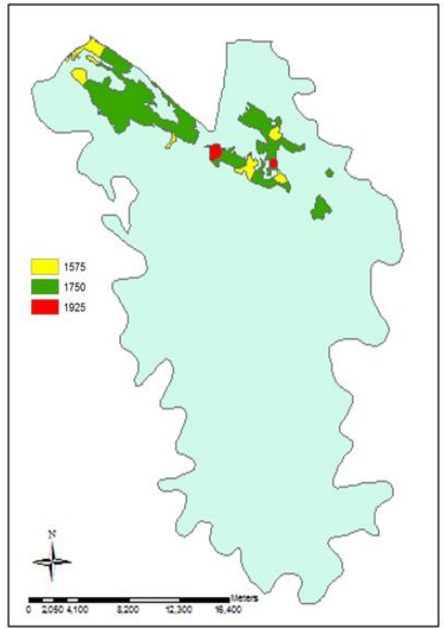

e) Dry farming wheat and barley straw

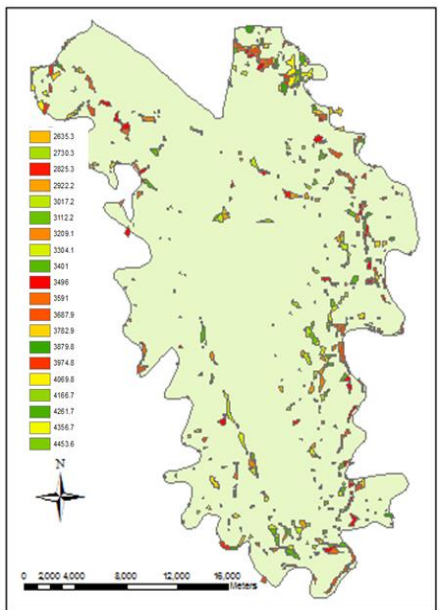

c) Bean straw

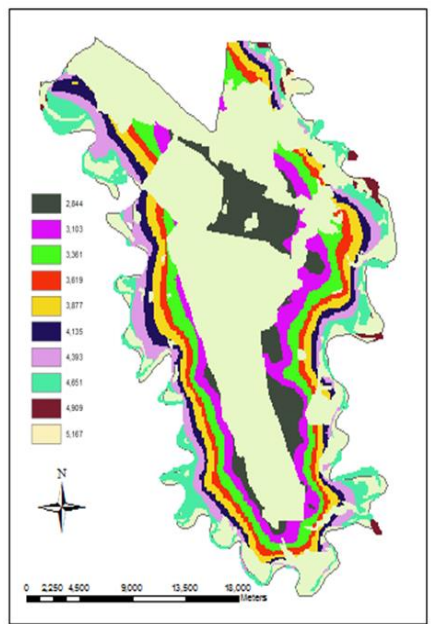

f) Irrigated farming wheat and barley straw

Figure 3. Available Field Crop Residues (kg/hectare)

Potential of energy generation from available residues in Shodirwan was 969589405 $\mathrm{kWh} /$ year. Of all the residues, the sugarcane residues had the greatest share of the total potential of energy generation with $79.15 \%$. Energy potential of sugarcane residues was $767420725 \mathrm{kWh} /$ year that $509945975 \mathrm{kWh}$ related to bagasse and $257474750 \mathrm{kWh}$ related to sugarcane top. Potential of energy generation from wheat and barley straw and paddy straw and husk were 132080000 (13.62\% of total potential) and 57280100 (5.91\% of total potential) $\mathrm{kWh} /$ year, respectively. Potential of energy generation from processing residues was $511946175 \mathrm{kWh} /$ year $(52.80 \%$ of total potential) while from field residues was 457643230 $\mathrm{kWh} /$ year $(47.20 \%$ of total potential). Base on the $\mathrm{CO} 2$ emission from electrical energy production in Iran that is $0.572 \mathrm{~kg} / \mathrm{kWh}[21,22]$, mitigation potential of $\mathrm{CO}_{2}$ emission, as a result of using crop residues energy in Shodirwan, was 554605 tonnes/year. 
Table 3. Annual Agricultural Residue Production in Shodirwan

\begin{tabular}{lllll}
\hline \multirow{2}{*}{ Residue } & \multirow{2}{*}{$\begin{array}{c}\text { Total residue } \\
\text { (tonnes/year) }\end{array}$} & $\begin{array}{l}\text { Available residue } \\
\text { (tonnes/year) }\end{array}$ & \multicolumn{2}{c}{ Residue energy } \\
\cline { 4 - 5 } & 381767.5 & 343590.8 & 509945975 & 52.59 \\
\hline Bagasse & 267263.3 & 187084.3 & 257474750 & 26.56 \\
Sugarcane top & 649030.8 & 530675.1 & 767420725 & 79.15 \\
Total sugarcane residue & 252986.4 & 88545.3 & 132080000 & 13.62 \\
Wheat and barley straw & 4509.3 & 1578.2 & 2301600 & 0.24 \\
Mung bean straw & 112479.3 & 39367.8 & 57280100 & 5.91 \\
Bean straw & 17464.7 & 6112.7 & 8506780 & 0.88 \\
Paddy straw & 2054.6 & 1849.2 & 2000200 & 0.21 \\
Paddy husk & 19519.4 & 7961.8 & 10506980 & 1.09 \\
Total paddy residue & 1038525.2 & 668128.2 & 969589405 & 100 \\
Total & & & & \\
\hline
\end{tabular}

Spatial potential of energy generation from crop residues in Shodirwan are illustrated in Figure 4. Spatial potential of residues to produce energy was calculated between 2900 to $61000 \mathrm{kWh} / \mathrm{hectare} / \mathrm{year}$. It can be seen from Figure 4 that spatial potential of energy generation from sugarcane residues in agro-industry is much greater than other crop residues in Shodirwan. Apart from the Imam Khomeini agro-industry, the spatial potential of residues to produce energy was between 2900 and $15500 \mathrm{kWh} / \mathrm{hectare} / \mathrm{year}$ and classified in 6 classes that classes of 2900-3500 and 3500-4500 kWh/hectare/year together were included $76.37 \%$ of total irrigated farming land (Except the agro-industry land) wile class of 10000-15500 $\mathrm{kWh} /$ hectare/year was included $1.62 \%$ of it (minimum area). The share of $4500-5500,5500-$ 7000 and $7000-10000 \mathrm{kWh} /$ hectare/year classes were $10.13 \%, 7.29 \%$ and $4.59 \%$ of total irrigated farming land (Except the agro-industry land), respectively.

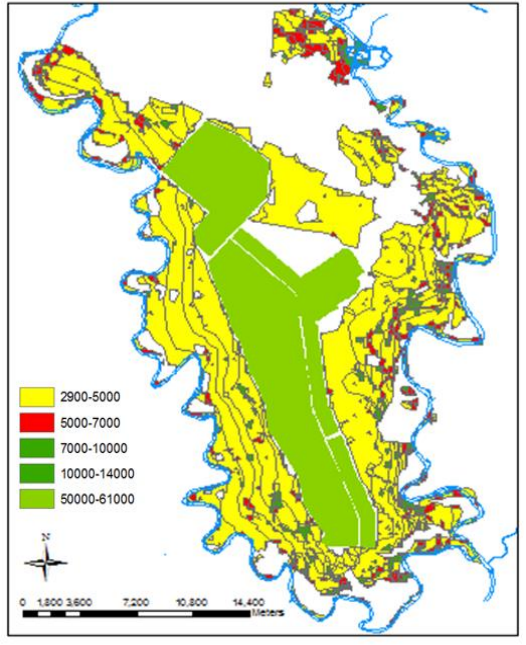

a) Total

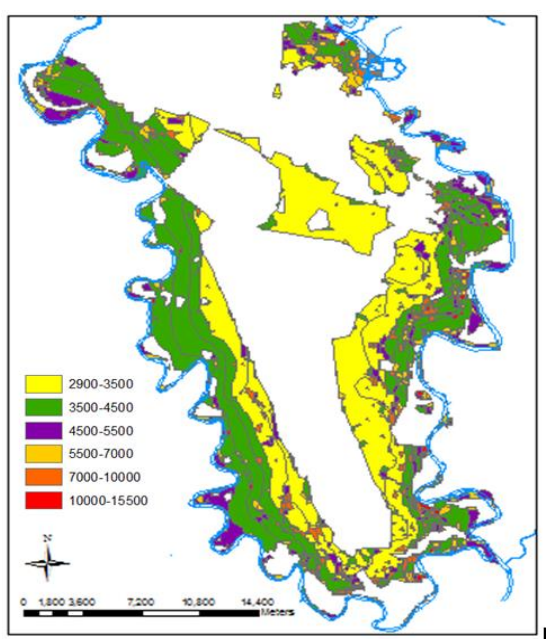

b) Without agro-industry

Figure 4. Spatial Potential of Energy Production from Crop Residues in Shodirwan (kWh/hectare/year) 


\section{Conclusion}

In this study, spatial potential of energy generation from agriculture residues was analyzed with using GIS in Shodirwan region of Iran. Data were collected by field random sampling, face to face questionnaire and, corresponding governing, research institutes and available literature. The available agriculture residues in Shodirwan were bagasse, sugarcane top, rice husk and straw of wheat, barley, bean, rice and mung bean. The total of crop residues that produced in this region was 1038525 tonnes/year that 668128 tonnes of it was available residues. Maximum of available crop residue related to bagasse. The total potential of energy production from available residues was $969589405 \mathrm{kWh} /$ year that sugarcane residues have the highest share with $79.15 \%$. The spatial potential of energy production from sugarcane residues was much greater than other crop residues. Spatial potential of residue to produce energy is calculated between 2900 to $61000 \mathrm{kWh} / \mathrm{hectare} / \mathrm{year}$.

\section{Acknowledgements}

This research was supported by University of Tehran. The authors also would like to thank Iran Meteorological Organization, Renewable Energies Organization of Iran (SUNA), Jahad Agriculture Organization of Khuzestan province and Iran National Cartographic Center for providing the data for this research study.

\section{References}

[1] U. K. Mirza, N. Ahmad and T. Majeed, “An overview of biomass energy utilization in Pakistan”, Renewable and Sustainable Energy Review, vol. 12, (2008).

[2] A. Mostafaeipour, "Feasibility study of offshore wind turbine installation in Iran compared with the world", Renewable and Sustainable Energy Review, vol. 14, (2010).

[3] A. Mostafaeipour, A. Sedaghatb, A. Dehghan-Niric and V. Kalantarc, "Wind energy feasibility study for city of Shahrbabak in Iran", Renewable and Sustainable Energy Review, vol. 15, (2011).

[4] M. Mirhosseini, F. Sharifi and A. Sedaghat, "Assessing the wind energy potential locations in province of Semnan in Iran", Renewable and Sustainable Energy Review, vol. 15, (2011).

[5] S. Yokoyama, T. Ogi and A. Nalampoon, "Biomass energy potential in Thailand", Biomass and Bioenergy, vol. 18, (2000).

[6] A. Demirbas, "Combustion systems for biomass fuels", Energy Sources Part A, vol. 29, (2007).

[7] M. F. Demirbas, M. Balat and H. Balat, "Potential contribution of biomass to the sustainable energy development", Energy Conversion and Management, vol. 50, (2009).

[8] Y. Matsumura, T. Minowa and H. Yamamoto, "Amount, availability, and potential use of rice straw (agricultural residue) biomass as an energy resource in Japan", Biomass and Bioenergy, vol. 29, (2005).

[9] M. Balat, "Biomass energy and biochemical conversion processing for fuels and chemicals," Energy Sources Part A, vol. 28, (2006).

[10] A. Demirbas, "Global renewable energy resources", Energy Sources Part A, vol. 28, (2006).

[11] Anonymous, "Energy Balance-Sheet", Iran Ministry of Energy. Power and Energy Planting Department publication, (2011).

[12] A. K. Hossain and O. Badr, "Prospects of renewable energy utilisation for electricity generation in Bangladesh", Renewable and Sustainable Energy Reviews, vol. 11, (2007).

[13] J. Singh, B. S. Panesar and S. K. Sharma, "Spatial availability of agricultural residue in Punjab for energy", Journal of Agricultural Engineering Today, vol. 27, no. 3, (2003).

[14] J. Singh, B. S. Panesar and S. K. Sharma, "Energy potential through agricultural biomass using geographical information system-A case study of Punjab", Biomass and Bioenergy, vol. 32, (2008).

[15] K. K. C. K. Perera, P. G. Rathnasiri, S. A. S. Senarath, A. G. T. Sugathapala, S. C. Bhattacharya and P. Abdul Salam, "Assessment of sustainable energy potential of non-plantation biomass resources in Sri Lanka”, Biomass and Bioenergy, vol. 29, (2005).

[16] C. Gokcol, B. Dursun. B. Alboyaci and E. Sunan, "Importance of biomass energy as alternative too ther sources in Turkey", Energy Policy, vol. 37, (2009).

[17] Y. Kar and Y. Tekeli, "The potential of biomass residues in Turkey and their importance as energy resources", Energy Sources, vol. 30, (2008). 
[18] S. C. Bhattacharya, V. M. Singamseth and V. M. Salam, "Assessment of bioenergy potential in Asia", Proceedings of the Asian seminar on fuel cell technology for rural electrification, Ludhiana, SESA, PAU, (1996).

[19] C. Frear, B, Zhao, G, Fu, M. Richardson and S. Chen, "Biomass inventory and bioenergy assessment", An evaluation of organic materials resources for bioenergy production in Washington State, (2005), pp. 123.

[20] B. M. Jenkis, "Biomass resources in California", California biomass collaborative, Department of Biological and Agricultural Engineering, University of California, (2005).

[21] S. h. Karaj, T. Rehl, H. Leis and J. Muller, "Analysis of biomass residues potential for electrical energy generation in Albania", Renewable and Sustainable Energy Reviews, vol. 14, (2009).

[22] A. Asakereh, A. Akram, S. Rafiee and A. Marzban, "Energy consumption and greenhouse gases emission form canned fish production in Iran a case study: Khuzestan province", Research Journal of Applied Sciences, Engineering and Technology, vol. 2, no. 5, (2010).

[23] A. Asakereh, M. J. Shiekhdavoodi and A. Akram, "Investigation of energy consumption in agriculture sector of Iran and their effect on air pollution and social cost", Research Journal of Applied Sciences Engineering and Technology, vol. 2, no. 5, (2010). 
International Journal of $u-$ and e-Service, Science and Technology Vol.7, No.1 (2014) 